DOI https://doi.org/10.30525/978-9934-588-81-5-1.36

\title{
ДІАГНОСТИЧНІ МОЖЛИВОСТІ ІМУНОГІСТОХІМІЧНОГО МАРКЕРА СD 138 У ДІАГНОСТИЦІ ХРОНІЧНОГО ЕНДОМЕТРИТУ У ЖІНОК 3 ОБТЯЖЕНИМ АКУШЕРСЬКО-ГІНЕКОЛОГІЧНИМ АНАМНЕЗОМ
}

\author{
Лоскутова Т. О. \\ доктор медичних наук, \\ професор кафедри акушерства та гінекології \\ Державний заклад «Дніпропетровська медична академія \\ Міністерства охорони здоров'я Украӥни» \\ Крячкова Н. В. \\ кандидат медичних наук, \\ асистент кафедри акушерства та гінекології \\ Державний заклад «Дніпропетровська медична академія \\ Міністерства охорони здоров'я Украӥни» \\ Чулков О. С. \\ лікар-інтерн, \\ кафедра акушерства, гінекології та перинатологї \\ факультету післядипломної освіти \\ Державний заклад «Дніпропетровська медична академія \\ Міністерства охорони здоров'я України» \\ м. Дніпро, Украӥна
}

Актуальність: однією з важливих причин зниження народжуваності та ранніх репродуктивних втрат $\epsilon$ інфекційно-запальні захворювання органів малого тазу. У зв'язку з цим, підвищена увага у вирішенні проблеми фертильності приділяється патології ендометрію, в якій важливе місце займає хронічний ендометрит (XE). Тривалий перебіг запального процесу в слизовій оболонці тіла матки призводить до структурних порушень ендометрію. В сучасній літературі все частіше використовується термін «ендометріальна дисфункція». До клінічних проявів дисфункції ендометрію відносять: ациклічні маткові кровотечі, тазовий біль, диспареунію, невиношування вагітності, безпліддя, невдачі допоміжних репродуктивних технологій, в тому числі екстракорпорального запліднення, при якому близько 65\% невдалих спроб [3]. Найбільш високі показники поширеності ХЕ відзначені у хворих зі звичним невиношуванням вагітності $-33,5-86,7 \%$. У пацієнток 3 
трубно-перитонеальним фактором безпліддя частота XЕ становить $12-68 \%$ [1]. Захворюваність на хронічний ендометрит, за даними різних авторів, варіює в широких межах від 0,8\% до 88\% [4]. 3 огляду на високий відсоток безсимптомних та атипових форм захворювання, на сьогоднішній день діагноз ХЕ верифікується на підставі виявлення в ендометрії в проліферативну фазу менструального циклу морфологічних та сонологічних ознак запалення $[2,5]$.

Мета дослідження: вивчити клініко-морфологічні та імуногістохімічні прояви хронічного ендометриту з метою подальшої розробки тактики відновлення репродуктивної функції у жінок з обтяженим акушерсько-гінекологічним анамнезом.

Дизайн дослідження. У проведеному дослідженні у 47 жінок з обтяженим акушерсько-гінекологічним анамнезом використовувалися наступні методи: клінічний, імуногістохімічний - дослідження ендометрію з визначенням експресії сіндекана-1 CD138 (кластер диференціації 138: мембранний протеїн, який використовують в якості імунологічного маркеру плазматичних клітин, ступінь присутності яких корелює з наявністю і активністю запального процесу). CD138 - маркер плазматичних клітин (ступінь вираженості хронічного ендометриту оцінюють за кількістю позитивних клітин в полі зору: 0 клітин норма, поодинокі клітини - слабо виражений, 2-3 - помірно виражений, більше 5 - виражений). Гістологічний (наявність запальних інфільтратів, які складаються 3 лімфоцитів та макрофагів; дистрофічноатрофічних змін ендометрію; гіпертрофічних змін, що супроводжуються гіперплазією слизової оболонки). Гістероскопічний метод (симптом «полуниці», ділянки гіперемії слизової оболонки, товщина ендометрію, точкові крововиливи, поліпоподібні наростання, набряк строми). Ультразвукове дослідження (зміна товщини ендометрію, підвищення ехогенності та неоднорідна ехоструктура ендометрію, нерівний контур ендометрію, дифузно-вогнищеві та кістозні зміни в субендометріальній зоні міометрію, синехії в порожнині матки, гіперехогенні включення в проекції базального шару).

Результати дослідження та їх обговорення. Характер обтяженого акушерсько-гінекологічного анамнезу пацієнток включав в себе: 2 самовільних аборта і більше (27,6\% жінок), 1-2 вагітності, що не розвивались (21,3\%), 2 і більше невдалих ЕК3 (21,3\%), гіперплазія і поліпоз ендометрію (29,8\%). Виходячи 3 даних Таблиці 1 гістероскопія інформативніше за все в діагностиці XЕ була у пацієнток з гіперплазією і поліпозом ендометрію. Ультразвукове і гістологічне дослідження показали свою значимість в діагностиці XЕ у жінок з 1 або 2 вагітностями, що не розвивались, в анамнезі. 
Таблиця 1

Відсоткове співвідношення діагностичних методів XE

\begin{tabular}{|c|c|c|c|c|c|}
\hline \multirow{2}{*}{$\begin{array}{c}\text { Загальна } \\
\text { кількість } \\
\text { обстежених }\end{array}$} & \multirow[b]{2}{*}{ Анамнез } & \multicolumn{4}{|c|}{ Вид обстеження, \% } \\
\hline & & CD138 & $\begin{array}{l}\text { Гістеро- } \\
\text { скопія }\end{array}$ & УЗД & $\begin{array}{l}\text { Гісто- } \\
\text { логія }\end{array}$ \\
\hline \multirow{4}{*}{$\begin{array}{c}47 \\
\text { пацієнток }\end{array}$} & $\begin{array}{c}2 \text { самовільних } \\
\text { абортів та більше }\end{array}$ & 30 & 25 & 20 & 25 \\
\hline & $\begin{array}{c}\text { 1-2 вагітності, що } \\
\text { не розвивалися }\end{array}$ & 28 & 20 & 24 & 28 \\
\hline & $\begin{array}{c}2 \text { та більше } \\
\text { невдалих ЕК3 }\end{array}$ & 29 & 25 & 21 & 25 \\
\hline & $\begin{array}{c}\text { Гіперплазія } \\
\text { та поліпоз } \\
\text { ендометрію }\end{array}$ & 34,5 & 27,6 & 17,2 & 20,7 \\
\hline
\end{tabular}

Хочемо зазначити, що питома вага імуногістохімічного методу діагностики XE з визначенням CD138 перевищувала інші у всіх категоріях пацієнток. Найбільш діагностично цінним визначення CD138 було у жінок з гіперплазією і поліпозом ендометрію в анамнезі в $33,4 \%$ випадків.

Висновки. Визначення імуногістохімічного маркеру CD138 в діагностиці хронічного ендометриту поряд 3 такими методами, як гістероскопія, ультразвукове та гістологічне дослідження демонструє свою високу діагностичну значимість, підтверджуючи діагноз, тим самим, дозволяючи виробити тактику по відновленню репродуктивної функції, усунути ендометріальну дисфункцію, вирішити проблему фертильності. Найбільш чутливим CD138 в діагностиці XЕ в даному дослідженні виявився відносно пацієнток з гіперплазією і поліпозом ендометрію в анамнезі в $33,4 \%$ випадків.

\section{Література:}

1. Колесніченко А.А., Петров Ю.А. Хронічний ендометрит і невиношування вагітності // Міжнародний журнал прикладних та фундаментальних досліджень. - 2019. - № 10-2. - С. 313-317;

2. Серебренікова К.Г., Арутюнян Н.А., Альохін А.І. Діагностика і клінічні критерії хронічного ендометриту. Гінекологія. 2018; 20 (6): 53-59. DOI: 10.26442 / 20795696.2018.6.180070

3. Ендометріальна дисфункція: алгоритм гістологічного та імуногістохімічного дослідження. Г. Х. Толібова, Т. Г. Траль, М. А. Клещев, I. М. Кветной, Е. К. Айламазян. Журнал акушерства та жіночих хвороб. Випуск 4, тому LXIV, 2015. С. 69-77. 
4. Kitaya K, Takeuchi T, Mizuta S, Matsubayashi H, Ishikawa T. Endometritis: new time, new concepts. Fertil Steril 2018; 110: 344-50.

5. Kumar, A., \& Kumar, A. (2017). Hysteroscopic Markers in Chronic Endometritis. Journal of Minimally Invasive Gynecology, 24 (7), 10691070. doi: 10.1016 / j.jmig.2017.02.007

DOI https://doi.org/10.30525/978-9934-588-81-5-1.37

\section{ПСИХОФІЗІОЛОГІЧНИЙ СТАН СПОРТСМЕНІВ-ІНВАЛІДІВ}

\section{Луковська О. Л.}

кандидат медичних наук, старший науковий співробітник,

професор кафедри фізіології та спортивної медицини Придніпровська державна академія фізичної культури і спорту

Кудрявцева В. $\mathbf{C}$. кандидат біологічних наук, старший науковий співробітник, доцент кафедри фізіологї та спортивної медицини Придніпровська державна академія фізичної культури і спорту

\section{Бурдаєв К. В.}

кандидат наук з фізичного виховання і спорту, старший викладач кафедри фізіології та спортивної медицини Придніпровська державна академія фізичної культури і спорту

\section{Головачов М. М.}

викладач кафедри фізіологї та спортивної медицини Придніпровська державна академія фізичної культури і спорту

Мізін В. В.

викладач кафедри фізіології та спортивної медицини, Придніпровська державна академія фізичної культури і спорту м. Дніпро, Украӥна

Сучасні реалії спортивної практики, складність і напруження спортивної діяльності, які зростають вимагають всебічного врахування наукових, а також психологічних закономірностей у роботі зі спортсменами-інвалідами. У функціональній діагностиці психічного стану спортсменів-інвалідів важлива роль належить інформації, що отримується за допомогою різноманітних психологічних тестів, які дозволяють оцінювати функціональний стан психіки в цілому, ії готовність до тренувальних та змагальних навантажень. 